\title{
Analytical Study Of Explosion Resistance Scaling On Reinforced Concrete Slab Under Free Air-Burst Blast Load
}

\author{
M.Gowtham \\ Department of Civil Engineering, \\ Mepco Schlenk Engineering College, \\ Sivakasi-626005
}

\author{
N.Chellakavitha \\ Department of Civil Engineering, \\ Mepco Schlenk Engineering college, \\ Sivakasi-626005
}

\begin{abstract}
In real condition the experimental study of scale on explosion resistance of reinforced concrete slab has highly expenses in conduction experiments. This analytical result of the work are overly desirable and close to the real time condition. This work indicates the obvious effect of scale on dynamic response resistance, stress strain behaviour, deflection of unilateral slab of reinforced concrete which are exposed to blast loading due to sudden explosion. To achieve this study reinforced concrete slab which were exposed to blast loading. Explosion test on this reinforced concrete slab which has different standoff distance. The slab are supported at its two ends using a suitable support condition. This work is analyze using the finite element software ABAQUS. The result of this experimental work is compared with the result obtained from the analytical result. From result the detachment in two slab of reinforced concrete both big and small is similar. The analytical behaviour of the slab is moreover same as that of the experimental behaviour.
\end{abstract}

Keywords: Blast load, dynamic response resistance, deflection, damage mode, scaling.

\section{INTRODUCTION}

About 70 per cent of India's production of fireworks and matches accounts from Sivakasi, town in Virudhunagar district in Tamilnadu. With around 480 firework factories employing about 40000 direct labourers and 100000 indirect labourers, an equal proportion of unauthorized sector is also controlling the manufacturing of firework products. These units manufacture about 300 unique varieties of fireworks. The market for fireworks is likely to grow at the rate of 10 per cent per annum. So, in a desperate attempt to improvise and meet the demand for light over sound, the industries have been experimenting dangerously, trying new processes and chemical combinations, which the workers are not used to. For the employers the business becomes a highly profitable one but the workers suffer a lot, which mostly goes unnoticed. Sometimes, child labourers are compelled to experiment with high-risk chemicals such as potassium chlorate, which emphasizes mainly on glittering aerial display but, which might also cause a catastrophic effect that may affect not only them but the whole neighborhood. Accidental explosions during the manufacturing process can cause loss of men, material, money and infrastructure. On the other hand, some of the unregistered units operate in the night hours, violating the rules as even an electric spark can trigger major accidents. A random survey conducted in 77 authorized industries and 16 unauthorized industries, recommended for construction of a blast resistant structure with necessary infrastructure facilities to minimize the effects of an explosion. An explosion is a sudden increase in volume and release of energy in a violent manner, usually with the generation of high temperature and release of gas. It is a chemical reaction when initiated, undergoes a very rapid decomposition releasing large volume of highly heated gas that exert pressure on the surroundings. Thus, the sudden conversion of chemical energy into kinetic energy with the release of heat, light and mechanical shock causes abrupt destruction. The Explosives Act, 1884 is a comprehensive law regulating the manufacture, possession, sale, transportation, exportation and importation of explosives in India. Based on this act, Explosives Rules 1983, Gas Cylinders Rules 1981 and Static and Mobile Pressure Vessels Rules 1981 were framed to prevent accidents at various points of handling of explosives in India.

Behavioral analysis and calculations of resistant construction which is used for protecting against dynamic loading such as aerial blast must be noticed both in military and civil and buildings with different uses. Herein blast tests on reinforced concrete symbols and in complete scale are necessary. However, these tests are somehow limited due to safety and economic issues. This research includes evaluation of scale on RC one-sided reinforced concrete under blast loading.

\section{FREE AIR BURST LOADING}

When a blast is occurred next to or over a construction that there is not any kind of reinforcement of first shock between the source of explosives and construction, in that case the load of blast on construction pressure is called open space blast.

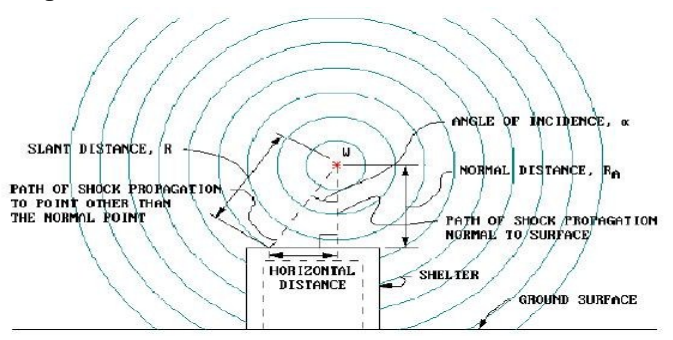

Figure 1.blast due to explosion in open space(TM5-1300, 1969). 


\subsection{SCALING RULE OF WOVE BLAST}

Hopkinson-Kornez scaling rule which is usually known as cube root has the most usage in scaling blast (Mays and Smith, 1995; Bangash, 1993). Consider two bombs with $\mathrm{W} 1$ and $\mathrm{W} 2$ weights that have $\mathrm{d} 1$ and $\mathrm{d} 2$ diameter respectively and are made from the same explosive.W1 and W2 are related to the.

$$
\mathrm{d}_{1} / \mathrm{d}_{2}=\left(\mathrm{w}_{1} / \mathrm{w}_{2}\right)^{1 / 3}
$$

\section{FREE AIR-BURST LOADING USING ABAQUS FEA SOFTWARE}

The slab is modelled using the finite element modeling software ABAQUS. The specimen tested using the software are of size $1000 \times 1000 \times 40 \mathrm{~mm}$.

The analytical work of the experimental work is done using the ABAQUS software. The blast load is applied using the explicit dynamics in the ABAQUS. The TNT value used in the analytical work for $0.31 \mathrm{~kg}$ and the standoff distance is $0.4 \mathrm{~m}$.

After feeding the necessary data's in the software for the slab is loaded and the result is checked is compared using the result obtained from the experimental work.

Table 1. Properties of materials

\begin{tabular}{|l|c|l|l|}
\hline MATE & DEN & YOUNGS & POISS \\
RAL & SIT & MODULU & $\begin{array}{l}\text { ONS } \\
\text { RATI } \\
\text { Y }\end{array}$ \\
& $\begin{array}{c}\mathbf{( k g} / \\
\left.\mathbf{m}^{\mathbf{3}}\right)\end{array}$ & & \\
& & & \\
\hline Concrete & 2500 & 28.3 & 0.2 \\
\hline Re-bars & 7850 & 200 & 0.3 \\
\hline
\end{tabular}

Table 2. Specification of blast loading

\begin{tabular}{|c|c|c|c|c|}
\hline $\begin{array}{l}\text { SCALE } \\
\text { FACTO } \\
\text { R }\end{array}$ & $\begin{array}{l}\text { DIMENS } \\
\text { ION(mm) }\end{array}$ & $\begin{array}{l}\text { EXPLO } \\
\text { SION } \\
\text { MASS(k } \\
\text { g) }\end{array}$ & $\begin{array}{l}\text { STAND } \\
\text { OFF } \\
\text { DISTAN } \\
\text { CE(m) }\end{array}$ & $\begin{array}{l}\text { SCALE } \\
\text { DISTANC } \\
\mathrm{E}\left(\mathrm{m} / \mathrm{kg}^{\mathbf{1} 3}\right)\end{array}$ \\
\hline 1.25 & $\begin{array}{l}1000 \times 1000 \\
\text { X40 }\end{array}$ & 0.31 & 0.4 & 0.591 \\
\hline
\end{tabular}

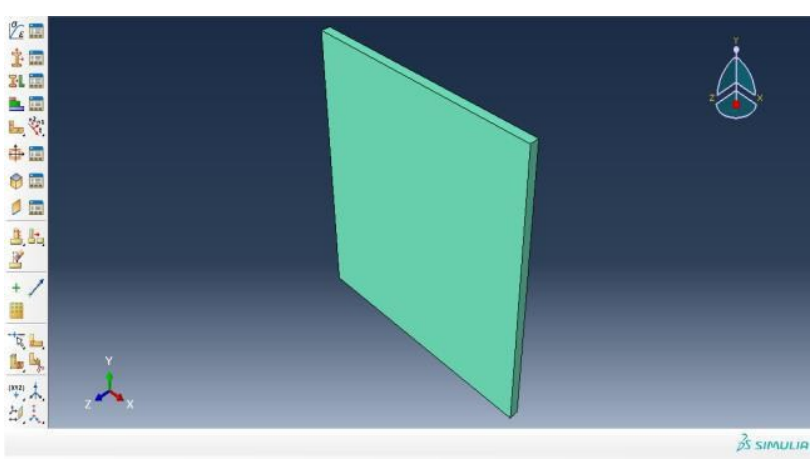

Fig 1. Property assigned specimen.

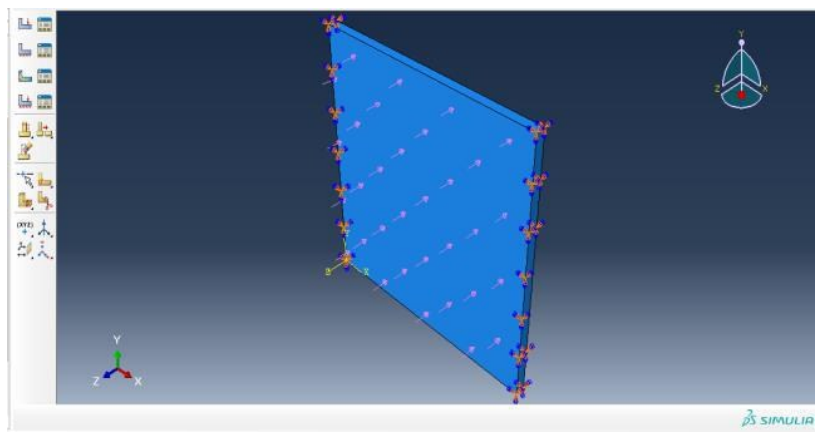

Fig 2. Load and boundary conditions applied specimen.

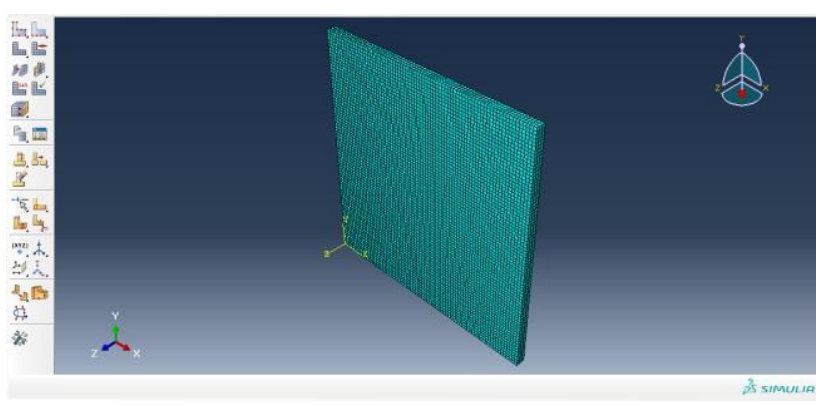

Fig 3. Meshed model of the specimen.

\section{RESULT AND DISCUSSION}

The deflection value obtained in the analytical study of the reinforced concrete slab slightly varies when compared to the experimental value. The variation in the deflection is due to the application of the load in open environment which alter the load effect on the test specimen. The deflection of the first slab is about $9 \mathrm{~mm}$ where as in the analytical study the deflection is about $14.54 \mathrm{~mm}$ which is slightly higher. More over the deflection obtained for the analytical study is about plus or minus $5-10 \%$ 


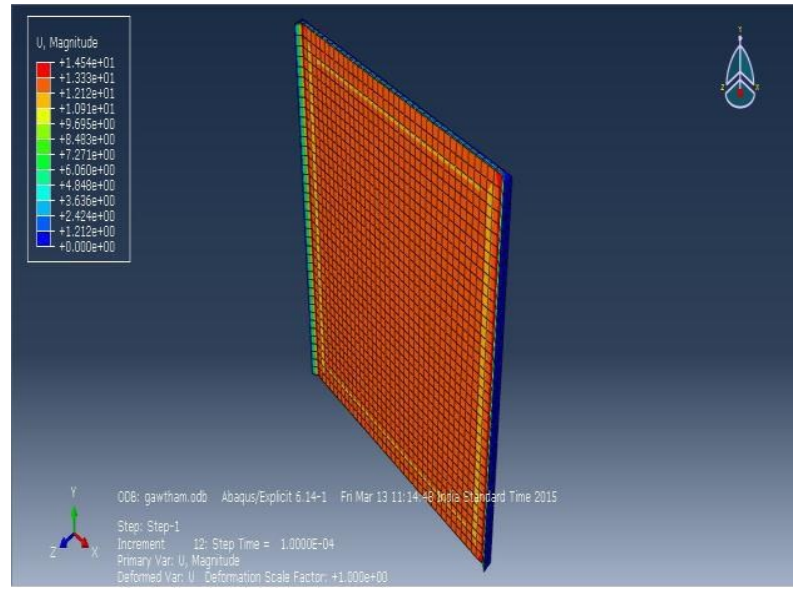

Fig 4. Deflection of the slab.

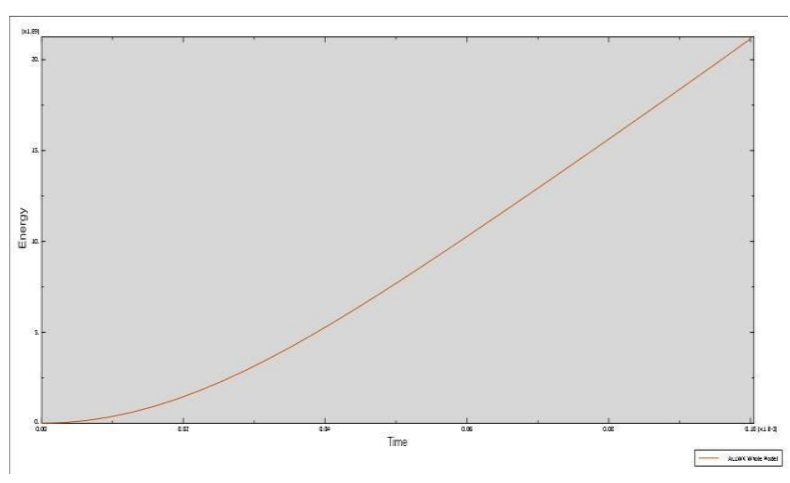

Fig 5. External work graph.

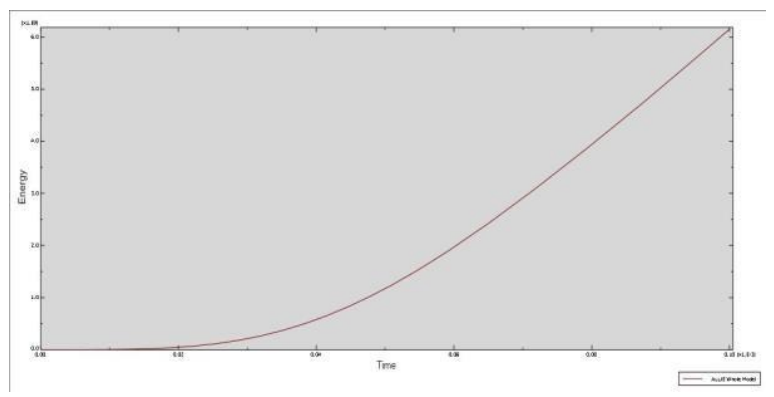

Fig 6. Internal work graph.

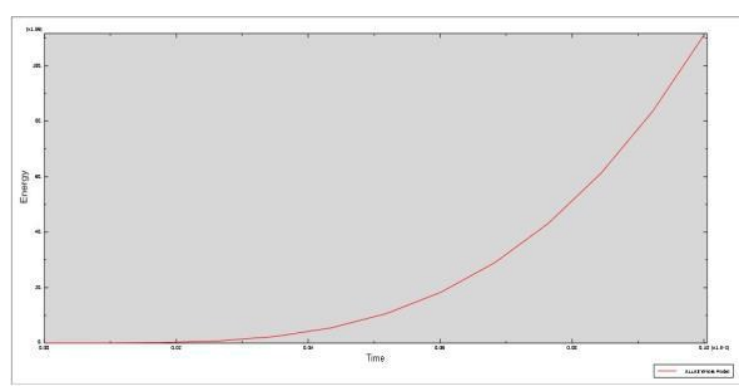

Fig 7. Strain energy graph.

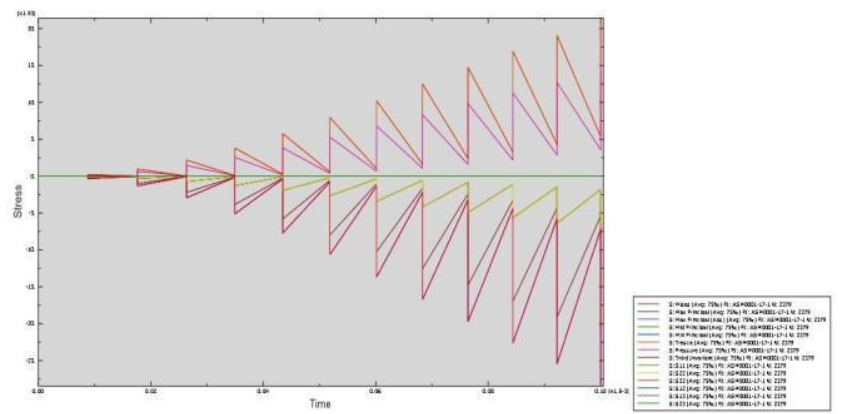

Fig 8. Stress vs Time graph.

Table 3. Comparison of experimental and analytical deflection.

\begin{tabular}{|c|c|c|c|c|}
\hline SCAL & DIMEN & EXPLO & CENTRA & ANALYT \\
E & SION & SIVE & L & ICAL \\
FAC & (MM) & MASS & $\begin{array}{c}\text { DEFLEC } \\
\text { TION }\end{array}$ & $\begin{array}{c}\text { DEFLEC } \\
\text { TION } \\
\text { TOR }\end{array}$ \\
& & (KG) & (MM) & (MM) \\
& & & & \\
& & & & \\
\hline 1.25 & $1000 \mathrm{X} 10$ & 0.31 & 15 & 14.54 \\
& $00 \mathrm{X} 40$ & & & \\
\hline
\end{tabular}

Table 4.Comparison of experimental and analytical $\delta / \mathrm{h}$.

\begin{tabular}{|c|c|c|c|c|}
\hline SCA & DIMEN & EXPL & EXPERIM & ANALY \\
LE & SION & OSIVE & ENTAL & TICAL \\
FAC & (MM) & & $\Delta / \mathbf{H}$ & $\boldsymbol{\Delta} / \mathbf{H}$ \\
TOR & & $\begin{array}{c}\text { MASS } \\
\text { (KG) }\end{array}$ & & \\
& & & & \\
\hline 1.25 & $\begin{array}{c}1000 X 10 \\
00 X 40\end{array}$ & 0.31 & 0.375 & 0.388 \\
& & & & \\
\hline
\end{tabular}

\section{CONCLUSION}

The considered scaling principals for this experiment were like similitude geometric while scaling for blast load was based on Hopkinson rule. hits.

The crack develop more at the place where the blast effect

The damage level of the slab is mainly due to the strain which caused by the blast load. The damage level of the slab will be more when amount of explosion amount is more. 
From the result the failure patter are the same for almost all of cases. Bigger samples face with more damages and smaller one face less damages.

The surface which expose to the blast loading are damaged seviour which causes more damage. The standoff distance, explosion mass has the major influence over the damage of the slab.

The spacing and the size of the reinforcement plays a major role. Less spacing and bigger size reinforcement sample will encounter a less amount of damage.

The locally damages on concrete slabs with bigger scale compared to concrete slabs with smaller scale factor indicate that by increasing the number of scale, this amount decreases.

\section{ACKNOWLEDGMENTS}

This paper is published with the permission of the guide, department of civil engineering,Mepco Schlenk engineering college.

\section{REFERENCES}

[1] Lok, T.S, Xiao J.R.; 1999.Steel-fibre-reinforced concrete panels exposed to air blast loading; Proc Inst Civil Eng Struct Build; 134:319e31.

[2] Mays, G.C; Hetherington, J.G; Rose, TA.;1999. Response to blast loading of concrete wall panels with openings; ASCE J StructEng; 125(12):1448e50. Tavel, P. 2007 Modeling and Simulation Design. AK Peters Ltd.

[3] Mosalam, K.M; Mosallam, A.S.; 2001.Nonlinear transient analysis of reinforced concrete slabs subjected to blast loading and retrofitted with CFRP composites; Compos Part B-Eng; 32:623e36.

[4] Mosallam, A; Haroun, M; Mosalam, K.M.; 2001.Repair and rehabilitation of reinforced and unreinforced concrete slabs with polymer composites, In: Forde MC, editor. Proceedings of the structural faults Repair-2001. London, UK. Edinburgh UK: Engineering Technics Press; 2001, July 4e6.A keynote paper, CD-ROM.

[5] Lawver, D; Daddazio, R; Jin Oh, G; Lee, C.K.B; Pifko,

A.B; Stanley, M.; 2003.Simulating the response of composite reinforced floor slabs subjected to blast loading; ASME Int Mech Eng Cong Wash DC;15e22.

[6] Ngo, T.; 2005.Behaviour of high strength concrete subject to impulsive loading; Ph.D. thesis, Univ. of Melbourne, Australia.

[7] Luccioni, B.M; Luege, M.; 2006.Concrete pavement slab under blast loads,Int J Impact Eng; 32:1248e66.

[8] Lu, B; Silva, P.F.; 2007.Improving the blast resistancecapacity of RC slabs with innovative composite materials; Compos Part B-Eng; 38:523e34.

[9] Silva PF, Lu B. Blast resistance capacity of reinforced concrete slabs. (2009): J StructEng-ASCE; 135:708e16.

[10] Mcvay, M.K.; 1998.Spall damage of concrete structures. Technical Report SL 88e22; US Army Corps of Engineers Waterways Experiment Station. al study on the effectiveness of fiber sheet reinforcement on the explosive-resistant performance of concrete plates. Int Impact Eng;35:1702e8.

[11] Wu, C; Oehlers, D.J; Rebentrost, M; Burman, N;Whittaker, A.S.; 2009.Blast testing of ultrahigh performance fiber concrete slabs and FRP retrofitted RC slabs; EngStruct; 31:2060e9.

[12] Nash, P.T;Vallabhan, C.V.G; Knight, T.C.; 1995.Spall damage to concrete walls from close in cased and uncased explosions in air; ACI Struct J; 92(6):680e8.

[13] Rabczuk, T; Eibl, J; Stempniewski, L.; 2004.Numerical analysis of high speed concrete fragmentation using a mesh free Lagrangian method; EngFractMech;71(4e6):547e56.

[14] Wu, C; Nurwidayati, R; Oehlers, D.J.;2009.Fragmentation from spallation of RC slabs due to airblastloads; Int J Impact Eng; 36:1371e6.

[15] Rabczuk T, Eibl J.; 2003.Simulation of high velocity concrete fragmentation using SPH/MLSPH.Int J Numer Meth Eng; 56(10):1421e44.

[16] Xu, K; Lu, Y.; 2006.Numerical simulation study of spallation in reinforced concrete plates subjected to blast loading; Comput Struct; 84:431e8.

[17] Zhou, X.Q; Hao, H; Deeks, A.J.; 2005.Modeling dynamic damage of concrete slab under blast loading; In: Hao H,Lok TS, Lu GX, editors. Proceeding of the 6th AsiaPacific conference on shock and impact loads on structures, December, Perth, WA, Australia; p. 703e10. ISBN: 981-05-3550-3.

[18] Ngo, T; Mendis, P; Krauthammer, T.; 2007.Behavior of ultrahigh-strength pre-stressed concrete panels subjected to blast loading; J StructEng-ASCE; 133: 1582e90. 